\title{
Pengaruh Ukuran PerusahaanTerhadap Kinerja Intelectual Capital dengan Stuktur Kepemilikan sebagai Variabel Moderating Di Bursa Efek Indonesia
}

\author{
Haifah $^{1}$, Wiwik Fitria Ningsih ${ }^{2}$, Angga Ade Permana ${ }^{3}$ \\ STIE Mandala, Jember ${ }^{1,2,3}$ \\ Email: haifah@stie-mandala.ac.id',wiwik@stie-mandala.ac.id ${ }^{2}$, \\ anggaadepermana23@gmail.com ${ }^{3}$
}

\begin{abstract}
This study aims to test empirically regarding the effect of company size on the intellectual capital performance of banking companies listed on the Indonesia Stock Exchange. This study uses Classical Assumption Analysis, VA, VACA, VAHU and STVA to measure the Performance of Intellectual Capital also using Multiple Regression analysis, Determination Test , F test, $t$ test also Moderated Regression Analysis (MRA) To test empirically the effect of institutional ownership structure on the relationship between company size and intellectual capital performance of banking companies listed on the Indonesia Stock Exchange. The population of this study is 43 listed banking companies. in the Indonesia Stock Exchange in 20142018 where the research sample was taken using the simple random sampling method of 11 samples. The results show that the size of the company does not have an influence on the intellectual capital performance of commercial bank companies listed on the Indonesian Stock Exchange for the period 2014-2018. And that the institutional ownership structure has no effect on the relationship between company size and the intellectual capital performance of commercial bank companies listed on the Indonesia Stock Exchange for the period 2014-2018.
\end{abstract}

Keywords: Company Size; Intellectual Capital Performance; Institutional Ownership Structure

\section{Pendahuluan}

Era globalisasi ditandai dengan perkembngan ilmu pengetahuan dan teknologi yang sangat pesat kemampuan suatu negara di bidang ilmu pengetahuan dan teknologi menjadi salah satu faktor daya saing yang sangat penting. Munculnya knowledgebased economy dengan penerapan knowledge management telah membawa perubahan dalam nilai dan parameter persepsi terhadap parameter kerja perusahaan (Saleh, et. Al., 2008). Disamping itu globalisasi, inovasi teknologi dan semakin ketatnya persaingan bisnis membuat setiap perusahaan meningkatkan keunggulan kompetitifnya agar tidak kalah bersaing di pasar, saat ini banyak perusahaan 
meningkatkan keunggulan kompetitifnya agar tidak kalah bersaing di pasar. Saat ini banyak perusahaan berpendapat bahwa knowledge asset lebih penting dari pada physical asset. Sebagai konsekuensinya, perusahaan mengubah pola industri yang digunakan dari productivity-based industries menjadi knowledge-based industries. Knowledge-based industries mempunyai karakteristik utama yaitu berbasis pada pengetahuan dan teknologi.

Di Indonesia, tren tentang intellectual capital mulai berkembang terutama setelah adanya PSAK No. 19 revisi (2007) tentang aset tidak berwujud. Walaupun tidak dijelaskan secara eksplisit sebagai intellecual capital, tapi setidaknya intellectual capital mulai mendapat perhatian di Indonesia. Menurut PSAK No.19 aktiva tidak berwujud adalah aktiva non-moneter yang dapat di identifikasi dan tidak mempunyai wujud fisik serta dimiliki untuk digunakan dalam menghasilkan atau menyerahkan barang atau jasa, disewakan kepada pihak lain, atau untuk tujuan administratif. Tetapi menurut Abidin (2000) intellectual capital di Indonesia belum dikenal secara luas. Hal ini terbukti dengan masih banyak perusahaan di Indonesia yang masih menggunakan konsep convensional based dalam menjalankan usahanya sehingga produk yang dihasilkan masih miskin teknologi. Disamping itu perusahaan-perusahaan tersebut kurang memperhatikan human capital, structur capital, dan customer capital. Maka yang diharapkan adalah perusahaan- perusahaan dapat memahami pentingnya intellectual capital yang berbasis management knowledge.

Intellectual capital sebagai faktor utama dalam meningkatkan nilai perusahaan dipengaruhi oleh beberapa aspek. Seperti yang diungkapkan Bonieet.al., (2005) faktor sebagai aspek penentu yang mempengaruhi intellectual capital adalah: (1) retensi kepemilikan; (2) biaya kepemilikan; (3) tata kelola struktur perusahaan. Selain dipengaruhi oleh struktur kepemilikan, menurut El;Bannany(2008) kinerja intellectual capital dipengaruhi oleh investasi pada teknoligi informasi, investasi pada intellectual capital, tingkat keuntungan, risiko perusahaan, jalan masuk kepasar, dan efisiensi perusahaan.

Struktur kepemilikan menjadi aspek yang menentukan kinerja intellectual capital. Hal ini disebabkan karena struktur kepemilikan akan mendorong 
terjadinya pertentangan pada manajer perusahaan. Pertentangan ini terjadi karena manajer harus memilih untuk menciptakan nilai lebih bagi perusahaan atau untuk memaksimalkan kepentingan pribadinya. Penelitian ini berbeda dengan penelitian yang dilakukan diperusahaan-perusahaan barat, karena di Indonesia struktur kepemilikannya dipengaruhi oleh perusahaan barat, struktur kepemilikannya tersebar, karena mempunyai tingkat aktivitas investasi yang tinggi.

Ukuran perusahaan yang besar juga dapat mendorong perusahaan dengan kepemilikan keluarga untuk untuk memasukan anggota keluarga atau kolega mereka dikarenakan semakin besar ukuran perusahaan maka birokrasi dan mekanisme organisasi dalam perusahaan semakin kompleks dan apalagi dengan adanya investor luar yang masuk ke perusahaan cenderung akan mendorong kepemilikan keluarga untuk memasukan anggota/keluarga untuk masuk ke perusahaan agar tetap mempunyai pengaruh yang cukup besar dalam perusahaan.

Penelitian mengenai pengaruh struktur kepemilikan terhadap kinerja intellectual capital telah dilakukan oleh Saleh,et.al., (2008) dengan mengambil sampel dari perusahaan di Malaysia. Sedangkan penelitian mengenai pengaruh tingkat keuntungan dan risiko perusahaan terhadap kinerja Intellectual capital telah dilakukan oleh El- Bannany,et.al., (2008) dengan mengambil pada kasus di United Kingdom. Penelitian mengenai kinerja intellectual capital telah banyak dilakukan dinegara lain, tetapi masih jarang dilakukan diIndonesia. Maka penelitian ini berusaha untuk mengungkapkan kinerja intellectual capitalperusahaan di Indonesia, khususnya pada perusahaan perbankan yang terdaftar di Bursa Efek Indonesia (BEI)

Sektor perbankan dipilih sebagai objek ideal penelitian ini karena (1) tersaji data laporan keuangan (neraca, laporan laba/ rugi) publikasian yang dapat diakses setiap saat; (2) bisnis perbankan adalah “intellectually” intensif (Firerdan William, 2003) ;(3) secara keseluruhan karyawan sektor perbankan “intellectually" lebih homogen dibanding dengan sektor ekonomi lainnya (Kuboand Saka, 2002) dalam Ulum (2006). Dimana sekarang banyak bertumbuhnya perusahaan yang membuat terjadi persaingan yang sangat ketat antar perusahaan, untuk mendapatkan keuntungan yang sebesar-besarnya dengan pengeluaran seminim-minimya. Dimana perusahaan 
dapat dengan menggunakan kinerja sesuai dengan kemampuan dan keahlian yang dimilki oleh karyawan, yang dimana dapat menambah kekayaaan suatu perusahaan. Berdasarkan latar belakang masalah yang telah diuraikan diatas maka tujuan penelitian ini adalah Untuk menguji secara empiris mengenai pengaruh ukuran perusahaan terhadap kinerja intellectual capital perusahaan perbankan yang terdaftar di Bursa Efek Indonesia dan untuk menguji secara empiris mengenai pengaruh struktur kepemilikan instusional terhadap hubungan antara ukuran perusahaan dengan kinerja intellectual capital perusahaan perbankan yang terdaftar di Bursa Efek Indonesia

\section{Tinjauan Pustaka}

\section{Ukuran Perusahaan}

Ukuran perusahaan mencerminkan besar kecilnya perusahaan yang tampakdalam nilai total asset perusahaan pada neraca akhir tahun (sujoko dan Soebiantoro,2007). Semakin besar total aset maka semakin besar pula ukuran suatu perusahaan. Perusahaan besar dengan jumlah aset yang sangat besar memiliki dana lebih banyak untuk diinvestasikan dalam intellectual capital. Ketersediaan dana dalam jumlah yang besar akan membuat pengelolaan dan pemeliharaan intellectual capital menjadi semakin optimal dan akan menghasilkan kinerja intellectual capital yang lebih tinggi (Putri, 2012). Selain itu perusahaan yang besar memiliki fasilitas yang lebih banyak dari pada perusahaan kecil. Fasilitas ini termasuk akses ke dan eksternal dan visibilitas dalam perekonomian, yang akn mencerminkan pentingnya perusahaan sehingga memungkinkan adanya dukungan dari pemerintah. Hal ini dapat menarik lebih banyak investor dan yang berkualitas baik. Staff yang berkualitas akan dapat meningkatkan kinerja intellectual capital perusahaan (ElBanany,2012).

\section{Intellectual Capital}

Definisi intellectual capital seringkali dimaknai secara berbeda. Stewartb(1997) menjelaskan bahwa modal intelektual dapat dipahami dalam tiga hal. Pertama, keseluruhan dari apapun yang seseorang ketahui di dalam perusahaan yang dapat memberikan keunggulan bersaing. Kedua materi intelektual pengetahuan, informasi, intellectual Property,pengalaman yang dapat digunakan untuk 
menciptakan kekayaan. Ketiga paket pengetahuan yang bermanfaat. Sesuai pendapat Mavridis (2005) inttelectual capital adalah suatu asset tidak berwujud dengan kemampuan member nilai kepada perusahaan dan masyarakat meliputi hak paten atas kekayaan intellectual, hak cipta dan waralaba. Demikian pula definisi Martinez dan Garcia-Meca (2005) mengatakan itellectual capital adalah pengetahuan, informasi, kekayaan intelektual dan pengalaman yang dapat digunakan untuk menciptakan kekayaan.

\section{Value Added (VA)}

Tahap prtama dengan menghitung VA dihitung denagn selisih antara pendapatan oprasional dengan biaya oprasional non biaya tenaga kerja. Biaya tenaga kerja tidak diukatkan dalam perhitungan ini karena dalam model pulic, tenaga kerja merupakan entitas pencipta nilai.

$$
\mathrm{VA}=\text { Pendapatan operasional }- \text { biaya non BTK }
$$

\section{Value Added Capital Employed (VACA)}

VACA adalah indikator atau nilai laba yang diciptakan oleh satu unit dari physical capital. VACA adalah perbandingan antara value added (VA) dengan model fisik yang bekerja (capital employed/CA). Capital employed ini menunjukan bahwa hubungan harmonis yang dimiliki perusahaan dengan mitranya, baik yang berasal dari pemasok yang andal dan berkualitas, pelanggan yang loyal dan merasa puas dengan pelayanan perusahaan yang bersangkutan, serta hubungan perusahaan dengan pemerintah maupun dengan masyarakat sekitar (Belkaoui, 2003). Dalam proses penciptaan nilai intellectual potensial yang direpresentasikan dalam biaya karyawan tidak dihitung sebagai biaya (input) (Tan et al., 2007).

Pulic (1998) mengasumsikan bahwa jika satu unit CA menghasilkan return yang lebih besar pada sebuah perusahaan, maka perusahaan tersebut mampu memanfaatkan CA dengan lebih baik. Jadi pemanfaatan lebih CA adalah bagian dari intellectual capital perusahaan. Ketika membandingkan lebih dari sebuah kelompok perusahaan. VACA menjadikan sebuah indikator kemampuan intelektual perusahaan dalam memanfaatkan dalam modal fisiknya (Tan et al,.2007).

$$
\text { VACAi }=\frac{\text { Value added }}{\text { Capital employed }}
$$




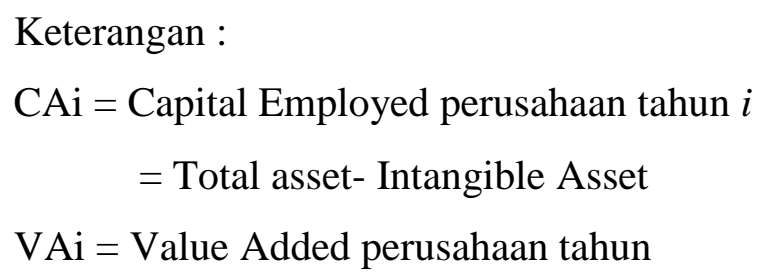

\section{Value Added Human Capital (VAHU)}

VAHU mengindikasikan seberapa besar value added (VA) yang diciptakan oleh setiap rupiah pengeluaran untuk pegawai (Tan et al., 2007). Stewart (1997) menjelaskan bahwa human capital adalah kemampuan karyawan untuk menciptakan produk yang dapat menjaring konsumen sehingga konsumen tidak akan berpaling pada pesaing. Humen capital mempresentasikan kemampuan perusahaan dalam mengelola sumber daya manusia dan menganggap manusia atau karyawan sebagai asset strategis perusahaan karena pengetahuan yang mereka miliki. VAHU dihitung dengan membagi value added yang diciptakan perusahaan dengan total salaries dan wages. Perhitungan ini mengasumsikan bahwa HC sebagai sesuatu investasi daripada sebagai expenses dan akan diakui sebagai asset pada neraca (Pulic, 2000 dalam Saleh et al., 2008).

Hubungan antara VA dan human capital (HC) mengindikasikan bahwa kemampuan HC adalah menciptakan nilai pada sebuah perusahaan. Pulic (1998) berpendapat bahwa biaya gaji dan upah merupakan indikator bagi HC. Ketika VAHU dibandingkan antara perusahaan, VAHU menjadi sebuah indikator kualitas sumber daya perusahaan VAHU juga sebagai kemampuan perusahaan mengahasilkan nilai tambah untuk setiap rupiah yang dikeluarkan pada HC (Kuryanto dan Syafruddin, 2008).

$$
\text { VAHU }=\frac{\text { Value Added }}{\text { Huamn Capital }}
$$

\section{Structural Capital Value Added (STVA)}

SYTVA menunjukkan kontribusi structural capital (SC) dalam pembentukan nilai tambah. Salah satu bagian dari structural capital adalah hubungan harmonis yang dimiliki perusahaan dengan mitranya, baik yang berasal dari pemasok yang andal dan berkualitas, pelanggan yang loyal dan merasa puas dengan pelayanaan perusahaan yang bersangkutan, serta perusahaan dengan pemerintah maupun dengan masyarakat sekitar (Belkaoui, 2003). 
Dengan model yang dikembangkan Pulic ini, STAVA dihitung dengan membagi structural capital (SC) dengan value added (VA). Dalam model Pulic. SC di peroleh dari VA dikurangi HC. STVA menunjukkan kontribusi modal struktur dalam penciptaan nilai maka akan semakin besar kontribusi SC (Tan et al., 2007). Pulic (1998) menyakitkan terdapat hubungan proporsi yang berkebalikan antara HC dan SC.

$$
\text { STVAi }=\frac{\text { Structural } \text { Capital }}{\text { Value Added }}
$$

Ketrangan :

$$
\begin{aligned}
\mathrm{VAi} & =\text { Value Added perusahaan thaun } \mathrm{i} \\
\mathrm{SCi} & =\text { Structural Capital perusahaan tahun } \mathrm{i} \\
& =\text { VAi-Hci }
\end{aligned}
$$

\section{Struktur Kepemilikan}

Para peneliti berpendapat bahwa struktur kepemilikan perusahaan memiliki pengaruh terhadap perusahaan. Tujuan perusahaaan sangat ditentukan oleh struktur kepemilikan, motivasi pemilik dan kreditur corporate governance dalam proses insentif yang membentuk motivasi manajer. Pemilik akan berusaha membuatberbagai strategi untuk mencapai tujuan perusahaan, setelah strategi dan mengalokasikan sumber daya yang dimiliki perusahaan untuk mencapai tujuan perusahaan. Kesemua tahapan tersebut tidak terlepas dari peran pemilik dapat dikatakan bahwa peran pemilik sangat penting dalam menentukan keberlangsungan perusahaan.

\section{Kerangka Konseptual}

Kerangka Konseptual dirancang seperti yang terlihat pada gambar sebagai berikut :

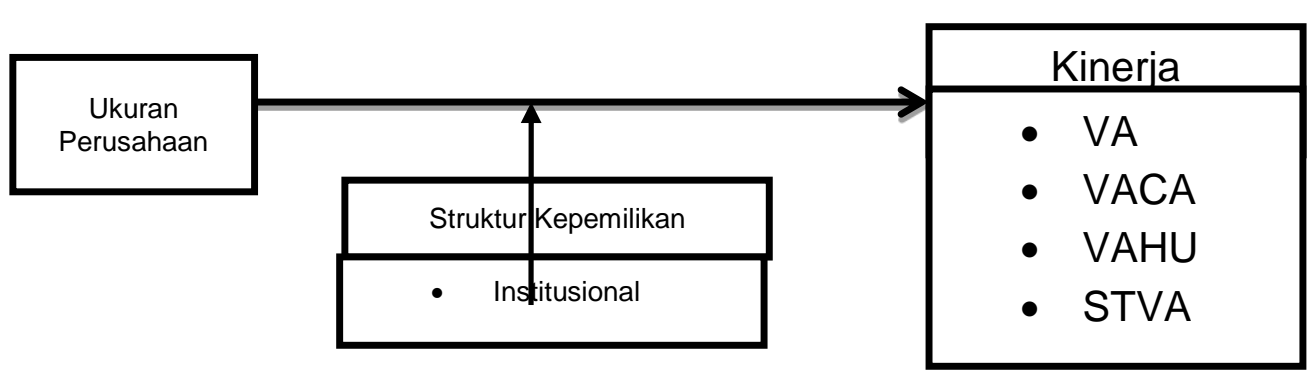

Keterangan : Diduga ukuran perusahaan ada hubungannya dengan kinerja intellectual capital dengan menghitung VA, 
VACA, VAHU, STVA untuk mengetahui kinerja Intellectual capital. Diuga struktur kepemilkan sebagai variabel moderating ada pengaruh terhadap ukuran perusahaan dengan kinerja intellectual capital.

\section{Hipotesis}

\section{Pengaruh ukuran perusahaan terhadap kinerja intellectual capital}

Ukuran perusahaan yang besar merupakan sumberdaya perusahaan yang dapat digunakan untuk memberikan value added bagi perusahaan sehingga dapat meningkatkan kinerja intellectual capital yang akan memberikan suatu karateristik tersendiri di perusahaan tersebut. Semakin besar total asset maka semakin besar pula ukuran suatu perusahaan. Perusahaan besar dengan jumlah asset yang besar memiliki dana lebih banyak untuk diinvestasikan dalam intellectual capital. Ketersediaan dana dalam jumlah yang besar akan membuat pengelolaan dan pemeliharaan intellectual capital menjadi semakin optimal dan akan menhasilkan kerja intellectual capital menjadi semkain optimal dan akan menghasilkan kinerja intellectual capital yang lebih tinggi (Putri, 2012). Selain tiu perusahaan yang besar memiliki fasilitas yang lebih banyak daripada perushan kecil. Fasilitas ini termasuk akses ke dana eksternal dan visibilitas dalam prekonomian, yang akakn mencerminkan pentingnya perusahaan sehingga memungkinkan adanya dukungan dari pemerintah. Hal ini dapat menarik ebih banyak investor dan staff yang berkualitas baik. Staff yang berkualitas mempunyai kinerja yang baik sehingga dapat meningkatkan kinerja intellectual capital perusahaan (El-Banany, 2012).

\section{H1: Diduga adanya pengaruh antara ukuran perusahaan terhadap kinerja} intellectual capital pada Bank umum yang terdaftar di BEI

\section{Pengaruh struktur kepemilikan institusional terhadap hubungan ukuran perusahaan dengan kinerja intellectual capital}

Semakin besar ukuran perusahaan maka kinerja IC yang dimiliki juga semakin tinggi. Hal ini karena perusahaan besar dengan jumlah asset yang besar cenderung memiliki dana lebih banyak untuk diinvestasikan dalam intellectual capital. Ketersediaan dana dalam jumlah yang besar akan membuat pengelolaan dan pemeliharaan. Intellectual capital menjadi semakin optimal dan akan menghasilkan kinerja intellectual capital yang lebih tinggi (putri, 2012).

The efficiency Argumentation Hypothesis yang dikembangkan oleh Sundaramurthy et.al., (2005) dalam the 2nd National Cnference UKWMS (2008, hal 8 dalam 
Novitasari, 2009) menyatakan bahwa orientasi investasi jangka panjang berupa dividen, sehingga investor institusional dalam kategoro ini sangan berkepentingan dalam kebijakan-kebijakan jangka panjang perusahaan. Investor institusional akan lebih memilih dan mendukung kebijakan yang dapat meningkatkan insentif jangka panjang bagi perusahaan, salah satunya adalah kebijakan peningkatan dan pengolaan intellectual capital. Intellectual capital yanag dikeloladan dimanfaatkan secara optimal diyakini akan dapat menghasilkan keunggulan kompetitif jangka jangka panjang yang berkelanjutan. Dengan adanya dukungan penuh dan pengawasan yang optimal dari para pemegang saham institusional maka efisiensi pengelolaan dan pemanfaatan intellectual capital akan semakin meningkat. Pengelolaan dan pemanfaatan intellectual capital secara optimal pada akhirnya akan menghasilkan kinerja intellectual capital yang tinggi.

\section{H2: Diduga adanya pengaruh antar kepemilikan intitusional terhadap hubungan antara ukuran bank dengan kinerja intellectual capitalpada Bank umum yang terdaftar di BEI}

\section{Metode Penelitian}

\section{Metode Pengumpulan Data}

Metode pengumpulan data yang diambil adalah metode dokumentasi yang dimana melihat dari laporan keuangan dari Neraca, Laba Rugi dan pemegang saham, perusahaan yang terdaftar di BEI. Dan metode studi pustaka yang dimana digunakan untuk mencari teori penunjang penelitian analisa data dan sumber data.

\section{Metode Analisis Data}

Penelitian ini bertujuan untuk menguji apakah ukuran perusahaan berpengaruh terhadap kinerja intellectual capital dan apakah struktur kepemilikan mempunyai pengaruh terhadap hubungan antara ukuran perusahaan dengan kinerja intellectual capiatal. Untuk itu akan digunakan teknik analisi regresi linier berganda dengan moderated regression analysis (MRA).

\section{Moderated Regression Analysis (MRA)}

Ada dua metode untuk mengidentifikasi ada tidaknya variable moderator yaitu analisis sub-group (sub kelompok) dan moderated regression analysis (MRA). Metodeyangakandigunakandalam penelitian ini adalah moderated regression 
analysis(MRA). Menurut Ghozali (2014), tujuan analisis regresi moderasi ini untuk mengetahui apakah variabelmoderating akan memperkuat atau memperlemah hubungan antara variabel independen dan variabel dependen.MRA menggunakan pendekatan analitik yang mempertahankan integritas sample dan memberikan dasar untuk mengontrol pengaruh variabel moderator. Metode ini dilakukan dengan menambahkan variabel perkalian antara variabel bebas dengan variabel moderasinya.

Model Analisis Regresi :

$$
\begin{array}{ll}
\text { VAIC = a + b1 SIZE }+\mathbf{b 2} \text { INST + b1.b2 + e } \\
\text { SIZE } & =\text { Ukuran Perusahaan } \\
\text { INST } & =\text { Kepemilikan Institusional }
\end{array}
$$

\section{Hasil Dan Pembahasan}

\section{Hasil Penelitian}

\section{Uji Asumsi Klasik}

Model yang digunakan untuk menganalisis data dalam penelitian ini adalah menggunakan regresi linier berganda dan uji hipotesis dengan menggunakan uji $\mathrm{R}^{2}$, uji F, dan uji t. Sebelum membahas tentang analisis data, terlebih dahulu dilakukan uji asumsi klasik yang digunakan untuk mengetahui gangguan-gangguan atau persoalan-persoalan pada regresi linier berganda.

\section{Uji Normalitas}

Berdasarkan pengujian dengan menggunakan uji kolmogorov smirnov diperoleh output yang dapat dilihat pada table sebagai berikut:

Tabel 1. Kolmogorov-Smirnov Test

One-Sample Kolmogorov-Smirnov Test

\begin{tabular}{|ll|r|}
\hline & & $\begin{array}{c}\text { Unstandardized } \\
\text { Residual }\end{array}$ \\
\hline $\mathrm{N}$ & Mean & 55 \\
Normal Parameters $^{\mathrm{a}, \mathrm{b}}$ & Std. Deviation & $0 \mathrm{E}-7$ \\
& Absolute & 1.49455519 \\
& Positive & .172 \\
Most Extreme Differences & Negative & .172 \\
& & -.108
\end{tabular}




\begin{tabular}{|c|c|}
\hline $\begin{array}{l}\text { Kolmogorov-Smirnov Z } \\
\text { Asymp. Sig. (2-tailed) }\end{array}$ & $\begin{array}{r}1.278 \\
.076\end{array}$ \\
\hline
\end{tabular}

Berdasarkan pada tabel 1 hasil uji normalitas kolmogorov-smirnov test diatas menunjukkan bahwa Asymp. Sig (2-tailed) 0,076 jika nilai signifikan < 0,05 maka distribusi data residual tidak normal dan jika nilai signifikan >0,05 maka data residual berdistribusi normal. Hasil penelitian ini menunjukan bahwa signifikan $0,075>0,05$, yang berarti data terdistribusi normal dan penelitian layak untuk dilanjutkan.

\section{Uji Multikolinearitas}

Tabel 2. Uji Multikolinearitas (VIF-Tolerance)

\begin{tabular}{|c|c|c|c|c|c|c|c|}
\hline \multicolumn{8}{|c|}{ Coefficients $^{\mathrm{a}}$} \\
\hline \multirow[t]{2}{*}{ Model } & \multicolumn{2}{|c|}{$\begin{array}{c}\text { Unstandardized } \\
\text { Coefficients }\end{array}$} & \multirow{2}{*}{\begin{tabular}{|c|}
$\begin{array}{r}\text { Standardized } \\
\text { Coefficients }\end{array}$ \\
Beta
\end{tabular}} & \multirow[t]{2}{*}{$\mathrm{t}$} & \multirow[t]{2}{*}{ Sig. } & \multicolumn{2}{|c|}{ Collinearity Statistics } \\
\hline & B & Std. Error & & & & Tolerance & VIF \\
\hline (Constant) & -7.529 & 6.972 & & -1.080 & .285 & & \\
\hline $\begin{array}{l}1 \text { Ukuran } \\
\text { perusahaan }\end{array}$ & .399 & .316 & 171 & 1.263 & .212 & 1.000 & 1.000 \\
\hline
\end{tabular}

Dari tabel 2 diatas menunjukkan tidak ada variabel bebas yang memiliki nilai tolerance lebih dari 0,10. Hasil perhitungan VIF menunjukkan bahwa seluruh variabel bebas memiliki nilai VIF kurang dari 10 sehingga dapat dikatakan bahwa model regresi tidak mengalami multikolinearitas dan penelitian layak untuk dilanjutkan.

\section{Uji Heteroskedastisitas}

Tabel 3. Uji Heteroskeastisitas (uji Glejser)

Coefficients $^{\mathrm{a}}$

\begin{tabular}{|c|c|c|c|c|c|}
\hline \multirow[t]{2}{*}{ Model } & \multicolumn{2}{|c|}{ Unstandardized Coefficients } & Standardized & \multirow[t]{2}{*}{$\mathrm{t}$} & \multirow[t]{2}{*}{ Sig. } \\
\hline & $\bar{B}$ & Std. Error & Beta & & \\
\hline $1 \quad$ (Constant) & 7.668 & 5.974 & & 1.284 & .205 \\
\hline
\end{tabular}




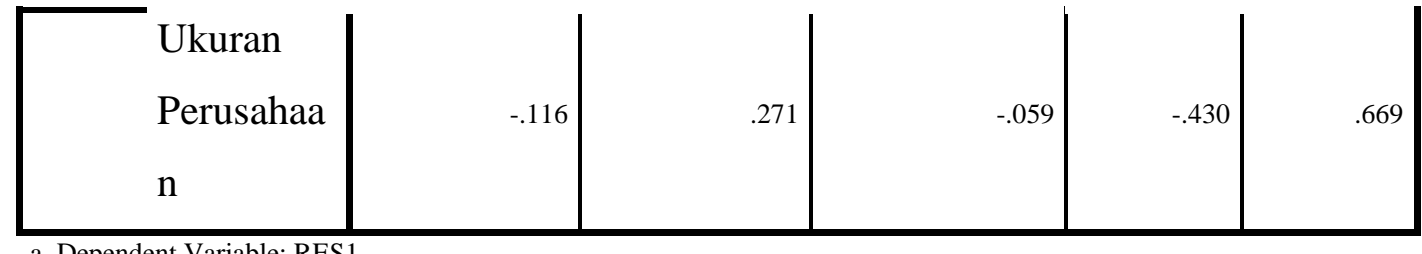

a. Dependent Variable: RES1

Dari tabel 3 diatas dapat dilihat apabila nilai signifikansi (Sig.) $>0,05$ maka tidak terjadi gejala Heteroskedastisitas, sehingga dapat dikatakan tidak ada gejala heteroskedastisitas karena Sig. 0,669> 0,05 dan penelitian layak untuk dilanjutkan.

\section{Uji Autokolerasi}

Tabel 4. Pengambilan keputusan ada tidaknya autokorelasi

\begin{tabular}{|l|l|l|}
\hline \multicolumn{1}{|c|}{ Hipotesis nol } & \multicolumn{1}{|c|}{ Keputusan } & \multicolumn{1}{c|}{ Keterangan } \\
\hline Tidak ada autokorelasi positif & Tolak & 0 < DW < dl \\
Tidak ada autokorelasi positif & Tidak ada & DI $\leq \mathrm{DW} \leq \mathrm{du}$ \\
Tidak ada korelasi negatif & Keputusan & 4-dl $\leq \mathrm{DW} \leq 4$ \\
Tidak ada korelasi negatif & Tolak & $4-\mathrm{du} \leq \mathrm{DW} \leq 4-\mathrm{dl}$ \\
Tidak ada autokorelasi positif, & Tidak ada & Du $<\mathrm{DW}<4-\mathrm{du}$ \\
baik positif atau negatif & Keputusan & \\
& Tdk ditolak & \\
\hline
\end{tabular}

Dari tabel Durbin Watson (DW) untuk $\mathrm{n}=11$ dengan banyaknya variabel bebas $(\mathrm{k}=1) \mathrm{du}=1,3421$ dan $\mathrm{dl}=0,9273$ dan $\mathrm{DW}=1,689$

Berikut adalah keputusan yang diperoleh untuk uji autokorelasi:

- $\mathrm{Du}<\mathrm{DW}<4-\mathrm{Du}$

- $1,3421<1,689<2,6759$

Berdasrakan criteria no 5 (Du $<$ DW $<4<$ - DU) table 4.5 maka dapt disimpulkan bahwa dalam penelitian ini tidak terjadi autokorelasi positif maupun negative.

Tabel 5. Uji Autokorelasi (Durbin-Watson)

\begin{tabular}{|c|c|c|c|c|c|}
\hline \multicolumn{6}{|c|}{ Model Summary ${ }^{\mathbf{b}}$} \\
\hline Model & $\mathrm{R}$ & R Square & Adjusted R Square & $\begin{array}{l}\text { Std. Error of the } \\
\text { Estimate }\end{array}$ & Durbin-Watson \\
\hline 1 & $.171^{\mathrm{a}}$ & .029 & .011 & 10.2284946 & 1.689 \\
\hline
\end{tabular}


a. Predictors: (Constant), Ukuran Perusahaan

b. Dependent Variable: VAIC

\title{
Perhitungan Kinerja Intellectual Capital
}

a. Value Added (VA)

\author{
Tabel 6. Data Value Added
}


Relasi : Jurnal Ekonomi, Vol. 17, No. 1, Januari 2021, hlm. 138-164

\begin{tabular}{|c|c|c|c|}
\hline No & Perusahaan & tahun & VA \\
\hline \multirow[t]{5}{*}{1} & BNI & 2014 & 1509634 \\
\hline & & 2015 & 1284576 \\
\hline & & 2016 & 952152 \\
\hline & & 2017 & 1393023 \\
\hline & & 2018 & 509836 \\
\hline \multirow[t]{5}{*}{2} & BRI & 2014 & -2608805 \\
\hline & & 2015 & -1495753 \\
\hline & & 2016 & -1800325 \\
\hline & & 2017 & -3249713 \\
\hline & & 2018 & -2267497 \\
\hline \multirow[t]{5}{*}{3} & BTN & 2014 & -886499 \\
\hline & & 2015 & -1155129 \\
\hline & & 2016 & -1471907 \\
\hline & & 2017 & -1551065 \\
\hline & & 2018 & -1454315 \\
\hline \multirow[t]{5}{*}{4} & $\mathrm{BCA}$ & 2014 & 1503768 \\
\hline & & 2015 & 20410534 \\
\hline & & 2016 & 23943281 \\
\hline & & 2017 & 29175679 \\
\hline & & 2018 & 42385623 \\
\hline \multirow[t]{5}{*}{5} & BUKOPIN & 2014 & -421195 \\
\hline & & 2015 & -497065 \\
\hline & & 2016 & -500536 \\
\hline & & 2017 & -425331 \\
\hline & & 2018 & -88259 \\
\hline \multirow[t]{5}{*}{6} & bank Mega & 2014 & -509704 \\
\hline & & 2015 & -639428 \\
\hline & & 2016 & -966014 \\
\hline & & 2017 & -1001595 \\
\hline & & 2018 & -1014494 \\
\hline \multirow[t]{4}{*}{7} & $\begin{array}{l}\text { BANK VICTORIA } \\
\text { INTERNASIONAL }\end{array}$ & 2014 & 133588180000 \\
\hline & & 2015 & 9639431000 \\
\hline & & 2016 & -8361404000 \\
\hline & & 2017 & -10274843000 \\
\hline
\end{tabular}


Relasi : Jurnal Ekonomi, Vol. 17, No. 1, Januari 2021, hlm. 138-164

\begin{tabular}{|r|l|r|r|}
\hline & & 2018 & -49980670000 \\
\hline 8 & BANK PAN INDONESIA & 2014 & -497976000 \\
\hline & & 2015 & -566342000 \\
\hline & & 2016 & -743318000 \\
\hline & & 2017 & -813027000 \\
\hline 9 & bank bumi arta & 2011 & -1677099000 \\
\hline & & 2012 & -34437148865 \\
\hline & & 2013 & -42736283974 \\
\hline & & 2014 & -59297877281 \\
\hline & & 2015 & -59611063490 \\
\hline 10 & bank cimb niaga & 2014 & -64736536442 \\
\hline & & 2016 & -741087 \\
\hline & & 2017 & -459452 \\
\hline & & 2018 & 3199861 \\
\hline & & 2014 & -1419357 \\
\hline 11 & Bank OCBC NISP & 2015 & -1840713 \\
\hline & & 2016 & -102716 \\
\hline & & 2017 & 67149 \\
\hline & & & 21535 \\
\hline & & & -277972 \\
\hline & & & -257951 \\
\hline
\end{tabular}


Relasi : Jurnal Ekonomi, Vol. 17, No. 1, Januari 2021, hlm. 138-164 
Relasi : Jurnal Ekonomi, Vol. 17, No. 1, Januari 2021, hlm. 138-164

b. Value Added Capital Employed

Tabel 7. Data VACA

\begin{tabular}{|r|l|r|r|}
\hline No & Perusahaan & \multicolumn{1}{l|}{ Tahun } & \multicolumn{1}{l|}{ VACA } \\
\hline 1 & BNI & 2014 & 0.00504796 \\
\hline & & 2015 & 0.00385407 \\
\hline & & 2016 & 0.00246254 \\
\hline & & 2017 & 0.003344 \\
\hline & & 2018 & 0.00100244 \\
\hline 2 & BRI & 2014 & -0.0055518 \\
\hline & & 2015 & -0.0029252 \\
\hline & & 2016 & -0.0028751 \\
\hline
\end{tabular}


Relasi : Jurnal Ekonomi, Vol. 17, No. 1, Januari 2021, hlm. 138-164

\begin{tabular}{|c|c|c|c|}
\hline No & Perusahaan & Tahun & VACA \\
\hline & & 2017 & -0.0040522 \\
\hline & & 2018 & -0.0025813 \\
\hline \multirow[t]{5}{*}{3} & BTN & 2014 & -0.0099471 \\
\hline & & 2015 & -0.0103369 \\
\hline & & 2016 & -0.0112214 \\
\hline & & 2017 & -0.0107284 \\
\hline & & 2018 & -0.0084648 \\
\hline \multirow[t]{5}{*}{4} & $\mathrm{BCA}$ & 2014 & 0.00393751 \\
\hline & & 2015 & 0.04607404 \\
\hline & & 2016 & 0.04824312 \\
\hline & & 2017 & 0.05281393 \\
\hline & & 2018 & 0.07131152 \\
\hline \multirow[t]{5}{*}{5} & BUKOPIN & 2014 & -0.0074009 \\
\hline & & 2015 & -0.0079488 \\
\hline & & 2016 & -0.0072413 \\
\hline & & 2017 & -0.0057158 \\
\hline & & 2018 & -0.0010859 \\
\hline \multirow[t]{6}{*}{6} & Bank Mega & 2014 & -0.0082567 \\
\hline & & 2015 & -0.0098249 \\
\hline & & 2016 & -0.014553 \\
\hline & & 2017 & -0.0150409 \\
\hline & & 2018 & -0.0148734 \\
\hline & BANK VICTORIAL & 2014 & 0.01132272 \\
\hline \multirow[t]{4}{*}{7} & INTERNASIONAL & 2015 & 0.00067171 \\
\hline & & 2016 & -0.0004362 \\
\hline & & 2017 & -0.0005103 \\
\hline & & 2018 & -0.0022665 \\
\hline \multirow[t]{5}{*}{8} & BANK PAN INDONESIA & 2014 & -0.0039932 \\
\hline & & 2015 & -0.0038346 \\
\hline & & 2016 & -0.0045327 \\
\hline & & 2017 & -0.0047133 \\
\hline & & 2018 & -0.0091645 \\
\hline \multirow[t]{5}{*}{9} & bank bumi arta & 2014 & -0.011653 \\
\hline & & 2015 & -0.0122686 \\
\hline & & 2016 & -0.0146936 \\
\hline & & 2017 & -0.0115871 \\
\hline & & 2018 & -0.009875 \\
\hline \multirow[t]{3}{*}{10} & bank cimb niaga & 2014 & -0.004515 \\
\hline & & 2015 & -0.0023274 \\
\hline & & 2016 & 0.01462016 \\
\hline
\end{tabular}


Relasi : Jurnal Ekonomi, Vol. 17, No. 1, Januari 2021, hlm. 138-164

\begin{tabular}{|r|l|r|r|}
\hline No & Perusahaan & \multicolumn{1}{l|}{ Tahun } & \multicolumn{1}{l|}{ VACA } \\
\hline & & 2017 & -0.0060874 \\
\hline & & 2018 & -0.0077066 \\
\hline 11 & NSIP & 2014 & -0.0017167 \\
\hline & & 2015 & 0.00084847 \\
\hline & & 2016 & 0.00022082 \\
\hline & & 2017 & -0.0026955 \\
\hline & & 2018 & -0.002141 \\
\hline
\end{tabular}

\section{c. Value Added Humant Capital}

Tabel 8. Data VAHU

\begin{tabular}{|c|c|c|}
\hline Perusahaan & Tahun & VAHU \\
\hline \multirow[t]{5}{*}{ BNI } & 2014 & 0.299402181 \\
\hline & 2015 & 0.230298786 \\
\hline & 2016 & 0.156504176 \\
\hline & 2017 & 0.205429078 \\
\hline & 2018 & 0.06921633 \\
\hline \multirow[t]{5}{*}{ BRI } & 2014 & -0.299833453 \\
\hline & 2015 & -0.155717629 \\
\hline & 2016 & -0.147181645 \\
\hline & 2017 & -0.230288912 \\
\hline & 2018 & -0.136603134 \\
\hline \multirow[t]{5}{*}{ BTN } & 2014 & -0.670776581 \\
\hline & 2015 & -0.776850817 \\
\hline & 2016 & -0.912441605 \\
\hline & 2017 & -0.972205246 \\
\hline & 2018 & -0.753786516 \\
\hline \multirow{5}{*}{$\mathrm{BCA}$} & 2014 & 0.288943941 \\
\hline & 2015 & 3.316108326 \\
\hline & 2016 & 3.487928236 \\
\hline & 2017 & 3.364778606 \\
\hline & 2018 & 4.356846769 \\
\hline \multirow[t]{5}{*}{ BUKOPIN } & 2014 & -0.686772782 \\
\hline & 2015 & -0.745754854 \\
\hline & 2016 & -0.573091046 \\
\hline & 2017 & -0.52576857 \\
\hline & 2018 & -0.389200512 \\
\hline \multirow[t]{4}{*}{ Bank Mega } & 2014 & -0.478129746 \\
\hline & 2015 & -0.549258911 \\
\hline & 2016 & -0.860839244 \\
\hline & 2017 & -0.91213798 \\
\hline
\end{tabular}


Relasi : Jurnal Ekonomi, Vol. 17, No. 1, Januari 2021, hlm. 138-164

\begin{tabular}{|c|c|c|}
\hline Perusahaan & Tahun & VAHU \\
\hline & 2018 & -0.914432251 \\
\hline \multirow{6}{*}{$\begin{array}{l}\text { BANK VICTORIA } \\
\text { INTERNASIONAL }\end{array}$} & 0014 & \\
\hline & 2014 & 1.811713395 \\
\hline & 2015 & 0.085755482 \\
\hline & 2016 & -0.054094671 \\
\hline & 2017 & -0.068255172 \\
\hline & 2018 & -0.357518711 \\
\hline \multirow[t]{5}{*}{ BANK PAN INDONESIA } & 2014 & -0.569222768 \\
\hline & 2015 & -0.51496357 \\
\hline & 2016 & -0.540037198 \\
\hline & 2017 & -0.468267709 \\
\hline & 2018 & -0.965935087 \\
\hline \multirow{5}{*}{ bank bumi arta } & 2014 & -0.57637543 \\
\hline & 2015 & -0.581254304 \\
\hline & 2016 & -0.677278451 \\
\hline & 2017 & -0.622827155 \\
\hline & 2018 & -0.603939363 \\
\hline \multirow[t]{5}{*}{ bank cimb niaga } & 2014 & -0.332663297 \\
\hline & 2015 & -0.159437611 \\
\hline & 2016 & 0.990959272 \\
\hline & 2017 & -0.432569766 \\
\hline & 2018 & -0.442894726 \\
\hline \multirow[t]{5}{*}{ NSIP } & 2014 & -0.108195792 \\
\hline & 2015 & 0.057255628 \\
\hline & 2016 & 0.015859292 \\
\hline & 2017 & -0.189266166 \\
\hline & 2018 & -0.151222438 \\
\hline
\end{tabular}

\section{d. Structur Capital Value Added}

Tabel 9. Data STVA

\begin{tabular}{|l|r|r|}
\hline Perusahaan & \multicolumn{1}{l|}{ Tahun } & \multicolumn{1}{l|}{ STVA } \\
\hline BNI & 2014 & -2.33999 \\
\hline & 2015 & -3.34219 \\
\hline & 2016 & -5.38961 \\
\hline & 2017 & -3.86786 \\
\hline & 2018 & -13.4475 \\
\hline Mandiri & 2014 & 4.335185 \\
\hline & 2015 & 7.42188 \\
\hline & 2016 & 7.794325 \\
\hline
\end{tabular}


Relasi : Jurnal Ekonomi, Vol. 17, No. 1, Januari 2021, hlm. 138-164

\begin{tabular}{|c|c|c|}
\hline Perusahaan & Tahun & STVA \\
\hline & 2017 & 5.342371 \\
\hline & 2018 & 8.320476 \\
\hline \multirow[t]{5}{*}{$\overline{\mathrm{BTN}}$} & 2014 & 2.490809 \\
\hline & 2015 & 2.287248 \\
\hline & 2016 & 2.095961 \\
\hline & 2017 & 2.028589 \\
\hline & 2018 & 2.326636 \\
\hline \multirow[t]{5}{*}{$\overline{\mathrm{BCA}}$} & 2014 & -2.46088 \\
\hline & 2015 & 0.698442 \\
\hline & 2016 & 0.713297 \\
\hline & 2017 & 0.702804 \\
\hline & 2018 & 0.770476 \\
\hline \multirow[t]{5}{*}{ BUKOPIN } & 2014 & 2.456086 \\
\hline & 2015 & 2.340923 \\
\hline & 2016 & 2.744923 \\
\hline & 2017 & 2.901978 \\
\hline & 2018 & 3.56937 \\
\hline \multirow[t]{5}{*}{ Bank Mega } & 2014 & 3.091483 \\
\hline & 2015 & 2.820635 \\
\hline & 2016 & 2.161657 \\
\hline & 2017 & 2.096325 \\
\hline & 2018 & 2.093575 \\
\hline \multirow{5}{*}{$\begin{array}{l}\text { BANK VICTORIA } \\
\text { INTERNASIONAL }\end{array}$} & 2014 & 0.448036 \\
\hline & 2015 & -10.6611 \\
\hline & 2016 & 19.48611 \\
\hline & 2017 & 15.6509 \\
\hline & 2018 & 3.797056 \\
\hline \multirow[t]{5}{*}{ BANK PAN INDONESIa } & 2014 & 2.756781 \\
\hline & 2015 & 2.941885 \\
\hline & 2016 & 2.851724 \\
\hline & 2017 & 3.135531 \\
\hline & 2018 & 2.035266 \\
\hline \multirow[t]{5}{*}{ bank bumi arta } & 2014 & 2.73498 \\
\hline & 2015 & 2.720417 \\
\hline & 2016 & 2.476498 \\
\hline & 2017 & 2.605582 \\
\hline & 2018 & 2.655795 \\
\hline \multirow[t]{3}{*}{ bank cimb niaga } & 2014 & 4.006042 \\
\hline & 2015 & 7.272046 \\
\hline & 2016 & -0.00912 \\
\hline
\end{tabular}




\begin{tabular}{|l|r|r|}
\hline Perusahaan & \multicolumn{1}{|l|}{ Tahun } & \multicolumn{1}{l|}{ STVA } \\
\hline & 2017 & 3.311766 \\
\hline & 2018 & 3.257873 \\
\hline NSIP & 2014 & 10.2425 \\
\hline & 2015 & -16.4655 \\
\hline & 2016 & -62.0545 \\
\hline & 2017 & 6.283565 \\
\hline & 2018 & 7.612775 \\
\hline
\end{tabular}

\section{Analisis Regresi Linier Berganda}

Pada pengujian ini menganalisis pengaruh antara Non Performing Loan, Good Corporate Governance, Return On Assets, dan Capital Adecuacy Ratio dalam memprediksi Price to Book Value pada bank umum BUMN yang terdaftar di bursa efek indonesia (BEI). Dimana hasil persamaan regresi dapat dilihat sebagai berikut:

Tabel 10. Analisis Regresi Linier Berganda

Coefficients $^{\mathrm{a}}$

\begin{tabular}{|c|c|c|c|c|c|c|c|}
\hline \multirow[t]{2}{*}{ Model } & \multicolumn{2}{|c|}{$\begin{array}{c}\text { Unstandardized } \\
\text { Coefficients }\end{array}$} & \multirow{2}{*}{$\begin{array}{c}\text { Standardized } \\
\text { Coefficients }\end{array}$} & \multirow[t]{2}{*}{$\mathrm{T}$} & \multirow[t]{2}{*}{ Sig. } & \multicolumn{2}{|c|}{ Collinearity Statistics } \\
\hline & B & Std. Error & & & & Tolerance & VIF \\
\hline $\begin{array}{l}\text { (Constant) } \\
\text { Ukuran } \\
\text { Perusahaan }\end{array}$ & $\begin{array}{r}-7.529 \\
.399\end{array}$ & $\begin{array}{r}6.972 \\
.316\end{array}$ & .171 & $\begin{array}{r}-1.080 \\
1.263\end{array}$ & $\begin{array}{l}.285 \\
.212\end{array}$ & 1.000 & 1.000 \\
\hline
\end{tabular}

a. Dependent Variable: VAIC

Dari table diatas, dapat diperoleh persamaan sebagai berikut :

$\mathrm{Y}=-7529+0.399 \mathrm{x}$

\section{Uji Hipotesis}

1. Uji t

Tabel 11. MODEL 1

\section{Hasil Uji Parsial (Uji t)}

Coefficients $^{\mathrm{a}}$

\begin{tabular}{|l|l|l|l|l|l|}
\hline Model & Unstandardized & Standardized & $\mathrm{T}$ & Sig. & Collinearity Statistics \\
\hline
\end{tabular}


Dari hasil tabel diatas menunjukkan bahwa :

1) Nilai thitung Ln 1,263<2,00856 dan nilai Sig. 0,212>0,05 artinya, ukuran perusahaan tidak berpengaruh secara signifikan terhadap nilai perusahaan sehingga $\mathrm{H}_{\mathrm{o}}$ ditolak.

Tabel 12. MODEL 2

\section{Hasil Uji Parsial (Uji t)}

Coefficients

\begin{tabular}{|c|c|c|c|c|c|c|}
\hline \multirow[t]{2}{*}{ Mod } & & \multicolumn{2}{|c|}{ Unstandardized Coefficients } & \multirow{2}{*}{$\begin{array}{c}\begin{array}{c}\text { Standardized } \\
\text { Coefficients }\end{array} \\
\text { Beta }\end{array}$} & \multirow[t]{2}{*}{$\mathrm{t}$} & \multirow[t]{2}{*}{ Sig. } \\
\hline & & $\mathrm{B}$ & Std. Error & & & \\
\hline \multirow{4}{*}{1} & (Constant) & -31.628 & 37.677 & & -.839 & .405 \\
\hline & Ukuran.Perusahaan & 1.671 & 1.789 & .515 & .934 & .355 \\
\hline & Struktur.Kepemilikan.Institusional & 14.204 & 22.449 & .580 & .633 & .530 \\
\hline & $\mathrm{Z}$ & -.736 & 1.034 & -.828 & -.711 & .480 \\
\hline
\end{tabular}

a. Dependent Variable: VAIC

1) Nilai thitung Ukuran perusahaan $-0,711<2,00856$ dan nilai Sig. 0,480 > 0,05 artinya, ukuran perusahaan tidak berpengaruh secara signifikan terhadap nilai perusahaan sehingga $\mathrm{H}_{\mathrm{o}}$ ditolak.

\section{Uji Statistik F}

Tabel 13. Uji F

ANOVA $^{\mathrm{a}}$

\begin{tabular}{|rl|r|r|r|r|r|}
\hline Model & & Sum of Squares & Df & Mean Square & F & Sig. \\
\hline \multirow{2}{*}{1} & Regression & 166.778 & 1 & 166.778 & 1.594 & \\
\cline { 2 - 6 } & Residual & 5544.971 & 53 & 104.622 & & \\
& Total & 5711.750 & 54 & & & \\
\hline
\end{tabular}

a. Dependent Variable: VAIC

b. Predictors: (Constant), Ukuran Perusahaan

Hasil dari tabel diatas menunjukan bahwa nilai $\mathrm{F}$ hitung sebesar 1,594 
sedangkan F tabel sebesar 2,77. F hitung > F tabel yaitu dengan nilai 1,594<2,77, yang artinya ukuran perusahaan tidak mempunyai pengaruh terhadap kinerja intellectual capital, sehingga dapat disimpulkan bahwa variabel bebas tidak berpengaruh signifikan secara simultan terhadap nilai perusahaan.

\section{Uji Koefisien Determinasi $\left(\mathbf{R}^{2}\right)$}

Tabel 14. Model 1 - Uji Koefisien Determinasi $\left(\mathbf{R}^{2}\right)$

\begin{tabular}{|l|r|r|r|r|r|}
\hline Model & \multicolumn{1}{|c|}{ Model Summary } \\
\hline 1 & R Square & Adjusted R Square & $\begin{array}{c}\text { Std. Error of the } \\
\text { Estimate }\end{array}$ & Durbin-Watson \\
\hline
\end{tabular}
a. Predictors: (Constant), Ukuran Perusahaan
b. Dependent Variable: VAIC

Berdasarkan tabel di atas diperoleh nilai koefisien determinasi $\left(\mathrm{R}^{2}\right)$ sebesar 0,029 atau 2,9\% hal ini berarti variabel ukuran perusahaan, terhadap VAIC sebesar 97,1\% dipengaruhi oleh variabel lainnya diluar model penelitian

Tabel 15. Model 2-Uji Koefisien Determinasi $\left(\mathbf{R}^{2}\right)$

\begin{tabular}{l}
\begin{tabular}{|l|r|r|r|c|}
\hline Model & \multicolumn{1}{|c|}{ M } & R Square & Adjusted R Square & $\begin{array}{c}\text { Std. Error of the } \\
\text { Estimate }\end{array}$ \\
\hline 1 & $.168^{\mathrm{a}}$ & .028 & -.029 & 10.4331836 \\
\hline
\end{tabular} \\
\hline
\end{tabular}

Berdasarkan tabel di atas diperoleh nilai koefisien determinasi $\left(\mathrm{R}^{2}\right)$ sebesar 0,028 atau 2,8\% hal ini berarti variabel ukuran perusahaan, terhadap VAIC sebesar 97,2\% dipengaruhi oleh variabel lainnya diluar model penelitian.

\section{Moderated Regression Analysis (MRA)}

Metode yang digunakan dalam penelitian setelah dilakukan analisis linier berganda adalah moderated regression analysis (MRA). Menurut Ghozali (2014), tujuan analisis regresi moderasi ini untuk mengetahui apakah variabel moderating akan memperkuat atau memperlemah hubungan antara variabel independen dan 
variabel dependen. MRA menggunakan pendekatan analitik yang mempertahankan integritas sample dan memberikan dasar untuk mengontrol pengaruh variabel moderator. Metode ini dilakukan dengan menambahkan variabel perkalian antara variabel bebas dengan variabel moderasinya. Berikut ini adalah hasil moderasi Struktur Kepemilikan Institusional, yaitu:

Tabel 16. Coefficients

Coefficients $^{\mathrm{a}}$

\begin{tabular}{|c|c|c|c|c|c|c|}
\hline \multirow[t]{2}{*}{ Moc } & & \multicolumn{2}{|c|}{ Unstandardized Coefficients } & \multirow{2}{*}{$\begin{array}{c}\begin{array}{c}\text { Standardized } \\
\text { Coefficients }\end{array} \\
\text { Beta }\end{array}$} & \multirow[t]{2}{*}{$\mathrm{t}$} & \multirow[t]{2}{*}{ Sig. } \\
\hline & & $\mathrm{B}$ & Std. Error & & & \\
\hline \multirow{4}{*}{1} & (Constant) & -31.628 & 37.677 & & -.839 & .405 \\
\hline & Ukuran.Perusahaan & 1.671 & 1.789 & .515 & .934 & .355 \\
\hline & Struktur.Kepemilikan.Institusional & 14.204 & 22.449 & .580 & .633 & .530 \\
\hline & $\mathrm{Z}$ & -.736 & 1.034 & -.828 & -.711 & .480 \\
\hline
\end{tabular}

a. Dependent Variable: VAIC

Berdasarkan tabel hasil uji diatas maka dapat dibentuk persamaan regresi dengan model taksiran sebagai berikut :

$$
Y=-31,628+1,671 X_{1}+14,204 Z-0,736 X_{1} Z
$$

Pengaruh Ukuran Perusahaan terhadap nilai perusahaan dengan struktur kepemilikan Institusional sebagai variabel moderasi.

Struktur kepemilikan Institusional sebagai variabel moderasi dari ukuran perusahaan sebesar -0,736 dan signifikansi sebesar 0,480 (>0,05) menyatakan bahwa variabel moderasi striktur kepemilikan institusional berpengaruh positif dan tidak signifikan terhadap hubungan ukuran perusahaan dengan kinerja intellectual capital.

\section{Hipotesis}

Pengujian hipotesis menunjukan seberapa jauh pengaruh suatu variabel bebas secara individual dapat menerangkan variasi variabel terikat, serta pengaruh interaksi antara variabel bebas dengan variabel moderasi terhadap variabel terikat melalui uji $\mathrm{F}$ dengan taraf signifikan 0,05 pada perusahaan Bank Umum yang Terdaftar di Bursa Efek Indonesia tahun 2014-2018 
- $\mathrm{H} 1$ = tidak adanya pengaruh antara ukuran perusahaan terhadap kinerja intellectual capital pada Bank Umum yang Terdaftar di Bursa Efek Indonesia 2014-2018

Analisis pengaruh ukuran perusahaan terhadap kinerja intellectual capital diketahui bahwa nilai $F_{\text {hitung }}$ sebesar 1,594 lebih kecil dibandingakan dengan $F_{\text {tabel }}$ 2,77 deangan tingakt signifikan 0,212 artinya ukuran perusahaan tidak berpengaruh terhadap kinerja Intellectual Capital

- H2:Tidak adanya pengaruh antara struktur kepemilikan institusional terhadap hubungan antara ukuran perusahaan dengan kinerja intellectual capital pada bank umum yang terdaftar di Bursa Efek Indonesia periode 2014-2018

Dari table 4.15 hasil uji $\mathrm{F}$ analisis pengaruh ukuran perusahaan dan struktur kepemilikan institusioanal tidak mempunyai pengaruh terhadap kinerja intellectual capital. Hal ini menunjukan bahwa $\mathrm{H}_{0}$ diterima yang berarti ukuran perusahaan dengan struktur kepemilikan institusional sebagai variabil moderating tidak memiliki pengaruh terhadap kinerja intellectual capital.

\section{Pembahasan Hasil Penelitian}

\section{Pengaruh Ukuran Perusahaan Terhadap Kinerja Intellectual Capital}

Berdasarkan hasil penelitian pada table 4.14 menunjukan bahwa t hitung sebesar 1,263 dengan tingkat signifikansi sebesar 0,212, antara ukuran perusahaan terhadap kinerja intellectual capital tidak signifikan. Sehingga dapat diartikan bahwa ukuran perusahaan tidak berpengaruh terhaadap kinerja intellectual capital. Hasil penelitian ini sesuai dengan Efandiani pada tahun 2011 yang menyatakan bahwa ukuran perusahaan tidak berpengaruh terhadap kinerja intellectual capital.Menurut Firer dan Williams (2013) yang menyatakan bahwa kinerja Intellectual berhubungan dengan kinerja perusahaan. Menurut Ferry dan Jones(dalam Sujianto, 2011), ukuran perusahaan menggambarkan besar kecilnya suatu perusahaan yang ditunjukan total aktiva, jumlah penjualan, rata-rata total aktiva. Jai, ukuran perusahaan merupakan ukuran atau besarnya asset yang dimilki oleh perusahaan. Dapat disimpulkan bahwa ukuran perusahaan tidak ada hubungan dengan kinerja intellectual.

2. Pengaruh Ukuran Perusahaan Terhadap Kinerja Intellectual Capital 


\section{dengan Struktur Kepemilikan Institusional Sebagai Variabel Moderating}

Berdasarkan hasil uji koefisien determinasi sebelum dan sesudah dimoderasi terdapat sebuah penurunan yang ditimbulkan dari adanya variabel struktur kepemilikan institusional. Hasil uji $\mathrm{R}^{2}$ model 1 (sebelum moderasi) menunjukkan bahwa nilai $\mathrm{R}^{2}$ sebesar 0,029 atau sama dengan 2,9\%, sedangkan hasil uji $\mathrm{R}^{2}$ model 2 (setelah dimasukkan variabel moderasi) menunjukkan bahwa nilai Ajusted $\mathrm{R}^{2}$ meningkat menjadi 0,028 atau sama dengan 2,8\% sehingga dapat disimpulkan bahwa struktur kepemilikan institusional sebagai variabel moderating tidak ada pengarung terhadap ukurang perusahaan dengan kinerja intellectual capital.

Penelitian ini sesuai dengan penelitian Pek Chen Gho (2005) yang menyatakan bahwa kira-kia $80 \%$ kemempuan penciptaan nilai (nilai VAIC) baik bank local maupun bank luar negri sebagian besar berhubungan dengan efisiensi human capital (HC) dibandingkan dengan efisiensi structur capital (SC) danefisiensi capital asset yang digunakan (CA). Nilai rata-rata kinerja intellectual capital perusahaan perbankan di Malaysia dilaporkan sebesar 7,91 seperti yang diperkirakan bank luar negeri secara intelektual lebih efisien daripada bank domestic.

\section{Kesimpulan}

Hasil penelitian menunjukan bahwa ukuran perusahaan tidak memilki pengaruh terhadap kinerja intellectual capital perusahaan bank umum yang terdaftar di bursa Efek Indonesia periode 2014-2018. Hasil penelitian juga menunjukan bahwa struktur kepemilikan institusional tidak berpengaruh terhadap hubungan antara ukuran perusahaan dengan kinerja intellectual capital perusahaan Bank umum yang terdftar di Bursa Efek Indonesia priode 2014-2018.

Saran bagi peneliti berikutnya yang ingin melakukan penelitian yang sejenis disarnkan untuk menambahkan rasio keuangan lainnya seperti nilai pasar dan ukuran perusahaan. Pada penelitian selanjutnya, menambahkan variabel moderating seperti kepemilikan manajerial dan kepemilikan asing. Dan bagi perusahaan sebaiknya memperhatikan kinerja perusahaan agar meningkatkan ukuran perusahaan. 


\section{DAFTAR PUSTAKA}

El-Bananny, Magdi. 2008. "A study of determinants of intellectual capital performance in bank: The UK case ." Journal of Intellectual Capital, Vol.9, No.3, h. 487-498.

El-Bananny, Magdi. 20012 . "Global financial crisis and the intellectual capital performance of UAE banks. " jurnal of Human Resource Costing \&Accounting, Vol.16,No.1, h. 20-36.

Efandiana, Ludita. 2011. “analisis factor-faktor yang berpengaruh terhadap ;Kinerja Intellectual capital." Skripsi tidak dipublikasikan. Fakultas Ekonomika dan Bisnis, Universitas Diponegoro.

Ghozali, Imam. (2014). Ekonometrika, Teori, Konsep, dan Aplikasi dengan IBM SPSS 22. Semarang: Badan Penerbit Universitas Diponegoro.

Jansendan Meckling. 1976. Theory of The Firm: Manajerial Behavior, Agency Cost and Ownership Structure. Journal Of Finance Economics 3: 30-60.

Kamath, G. B. 2007. The Intellectual Capital Performance of India Banking Sector. Jurnal of Intellectual Capital, Vol. 8, No.1.

Kuryanto, B dan M. Syarifudin. 2008. Pengaruh Modal Intelektual Terhadap Kinerja Perusahaan. Simposium Nasional Akuntansi XI. Pontianak.

Lisyani, T. T. 2003. "Kepemilikan Manajerial, Kebijakan Hutang dan Pengaruhnya Terhadap Kepemilkan Saham Institusional (Studi) pada Perusahaan Manufaktur di Bursa Efek Jakarta). “Jurnal Maksi, vol.3, h. 98-113.

Mavridis, D. G. 2004. The Intellectual Capital Performence of The Japanese BankingSector. Jurnal of Intellectual Capital, Vol.5, No. 3.

Novitasari. 2009the 2nd National Cnference UKWMS, hal 8

Pulic, A. 1998. Measuring the performance of intellectual potential in knowledge economy, Available [online] Tersedia: http.//www.measuringip.at/papers/Pulic/Vaictxt/ vaictxt.html. [12 Juli 2012].

Purnomosidhi, B. 2006. Praktik Pengungkapan Modal Intellectual pada Perusahaan Publikdi BEJ. Jurnal riset Akuntansi Indonesia 9:1.

Putri, Gelisa Dian Kharisma. 2010. “pengaruh struktur kepemilikan, Ukuran perusahaan, dan Umur Perusahaan terhadap Kinerja Intellectual." Skripsi 
tidak dipublikasikan, Fakultas ekonomika dan bisnis, Universitas Diponegoro.

PSAK. No 19 tahun 2007

Saleh, N.M, Rahman M.C.A., dan Hassan M.S. 2008. "Ownership Structure and Intellectual Capital Performance In Malaysia. "Asian Academy of Management Journal of Accounting and Financie,: 1-29.

Sundaramurthy et. Al., 2005. The efficiency Argumentation Hypothesis yang dikembangkan oleh

Sujoko dan Soebintoro, U. 2007. “Pengaruh Struktur Kepemilkan Saham, Leverage, Faktor Intern dan Faktor Ekstern Terhadap Nilai Perusahaan. “ jurnal Manajemen dan Kewirausahaan, vol. 9, no. I, h. 41-48.

Stewart, T.A. 1997. Intellectual capital: The new wealth of organization/ New York: Doubleday Dell Publishing Group.

Tan, H. P., D. Plowman, p. Huncock. 2007. IntellectualCapital and Financial Return of Comppaanies. Jurnal of Intellectual Capital, Vol. 8 No. 1.

Zhang, Yanren. 2011. "Family Firm Succession. "literature review. 